\title{
New Media and the Challenges of Boko Haram Terrorism: Proposing the Adoption of Human-Wearable Digital Technology
}

\author{
ADAMKOLO MOHAMMED IBRAHIM \\ MOHAMMED GUJBAWU \\ NASSIR ABBA-AJI \\ University of Maiduguri, Nigeria
}

\begin{abstract}
The Boko Haram terrorism, which began in 2009 has had a devastating impact on the society. So far, it has triggered one of the worst humanitarian crises in history and has been responsible for over 30 thousand deaths with over two million others displaced, mostly in the North-east of the country with sizeable spillovers into the neighboring countries of Chad, Niger and Cameroon. Boko Haram's primary goal was to create an Islamic caliphate in the region, and like other terrorist networks, uses the unconventional, hit-and-run guerrilla war tactics. This has rendered the insurgency to be a hard nut to crack, a phenomenon that is cited as one of the main reasons the group is able to continually carry out successful attacks despite being declared "technically defeated". Hence, this need to seek for alternative, 'unconventional' media as a tool for counterterrorism. The media, both new and traditional have been shown to play a critical role toward the de-Bokoharamization campaign of the Nigerian Federal Government in collaboration with its Western partners. However, due to the guerrilla tactics nature of the insurgency, human-wearable digital microchip technology such as radio frequency identification and wireless body area network systems have been suggested as capable of yielding desirable outcomes. Following a critical review of literature and taking from Laswell's communication model, this review article offers a digital communication counterterrorism model to complement the state's efforts toward the anti-terrorism campaign.
\end{abstract}

Keywords: Boko Haram conflict, de-bokoharamization campaign, digital wristband, human-wearable technology, counterterrorism

\section{INTRODUCTION}

In the 21st century, the media symbolizes the society and the society is a symbolic representation of the media (Croteau \& Hoynes, 2019; Siapera, 2018). The media generally, whether media of mass communication or new (digital) media play a pivotal role in the matrix of terrorism, insurgency and political violence and are put into positions where they can magnify or minimize these kinds of acts and their perpetrators, or, of course, they can provide coverage that avoids either one of those extremes (Nacos, 2002). The media are expected to actively and proactively play pivotal roles to minimize both the actual impacts of terrorism.

The media are always employed to wage psychological warfare on the targets through propaganda, heart-and-mind conquest campaigns, de-radicalization and reconciliatory efforts of providing incentives for extremists and insurgents to abandon violence and seek non-violence ways of seeking redress for their grievances. For instance, counter-narratives have been shown to be effective in this regard (Crelinsten, 2017; Othman \& Mat, 2018). Particularly, counter-narrative messages that foster inter-Islamic sects understanding can tremendously undermine the propaganda and extremist ideology of Boko Haram which promote hatred among different Islamic sects and label as infidel Muslim 
individuals and groups that do not follow their ideology (Ngige, Badekale \& HammanJoda, 2016). It is believed that the recruitment and radicalization processes for all suicide bombers are excruciatingly emotional (Barkindo, 2013; Bouzar, 2016). It is advisable that for any deradicalization, or de-Bokoharamization campaign to be effective and for peace to reign in the society, counter-narratives also must be emotional.

Boko Haram is an Islamist jihadist group based in North-eastern Nigeria. The group which is aligned to the so-called Islamic State in Iraq and the Levant (ISIL) is also active in Cameroon, Chad, and Niger republics. Boko Harams claims to propagate a Salafist-jihadist teaching of Islam and seeks to establish a caliphate, or Islamic state, in Nigeria. To attain this objective, the group has carried out large-scale attacks (mostly suicide bomb attacks) in the country, including an attack on the United Nations (UN) headquarters in Abuja in 2011, the abduction of nearly 300 Chibok schoolgirls in April 2014,8 the abduction of 111 Dapchi schoolgirls in February 2018 and the massacre of the northern Borno State town of Baga and surrounding villages in January 2015 which killed about 2,000 people (BBC News, 2015b; CFR, 2015; CNN, 2015; Reuters, 2011; UNSC, 2014; USDS, 2016; Washington Post, 2016).

Boko Haram was founded in 2002 at Kanamma village in northern part of Yobe State close to the border with Niger by a Salafist cleric called Muhammad Yusuf. The group later moved to Maiduguri, the capital of Borno State. Although Muhammad Yusuf called for the formation of an Islamic state in Nigeria, he did not pursue violence to realize his dream at that time. However, that approach changed in 2009, when Boko Haram members took up arms in response to a government crackdown and the killing of its leader. Ever since then, Boko Haram has launched paramilitary campaigns and terrorist attacks increasingly carried out by child suicide bombers, targeting the Nigerian Government, civilians and neighbouring countries (Barkindo, 2013). The loose security situation in and around Nigeria has enabled the terrorists to cross into Cameroon, Chad, and Niger in order to evade Nigerian security forces and perpetrate regional attacks. The terrorist group has been responsible for the death of over 30,000 (Aljazeera, 2019; Elden, 2014; Zenn, 2018 May) people since 2009.

In a bid to address the issues associated with engaging the media, especially new (digital) media in the counter-Bokoharamism campaign and restore lasting peace in the society, extant literature was critically reviewed and themes were derived from which a digital communication model proposed for adoption in the counterterrorism and managing human vulnerabilities was and recommended for adoption to compliment the Government's efforts toward eradicating Boko Haram terrorism and restoring lasting peace in the society. This paper discusses terrorism in a broad perspective, this is followed by a discussion about the factors leading to conflicts involving terrorism from global and local outlooks. A whole section on Engaging the Media in the Restoration of Peace for National Development is dedicated for the main gist of this paper, under which issues surrounding the relationships between the media and terrorism was discussed. Also discussed under that section is tips on how to engage the media for successful counterterrorism campaign.

\section{BACKGROUND}

Understanding Boko Haram Terrorism

Boko Haram terrorism has sparked a major humanitarian crisis that looks like religious cleansing, or faith cleansing because of its targeting mainly places of worship of both Muslims and Christians and later killing more Muslims than people of other faiths. In fact, the loss of life caused by Boko Haram (and the war against the group) has been staggering. 
So far, the conflict has forced more than two million Nigerians from their homes, with "profound humanitarian consequences," claimed nearly 40,000 since 29 May 2011 and more than 99,000 lives since February 2017 (CFR, 2012; Premium Times, 2017; Warner \& Matfess, 2017).

Concurrently, regional counterinsurgency organizations and the global community have been making concerted efforts indefatigably to combat Boko Haram and restore peace, prosperity and socio-economic development, which often resulted in limited success. According to $B B C$ News, due to the glaring weaknesses and insufficiencies of unilateral campaign by Nigeria to combat the terror group between 2010 and 2014, in January 2015 the $\mathrm{AU}$ deployed a 7,500-strong military force to the region. Subsequently, these forces that comprised of troops from Nigeria, Chad, Cameroon, Niger and Benin metamorphosed into the Multinational Joint Task Force (MJTF), an operation and dedicated to annihilating the insurgents (Assanvo, Abatan \& Sawadogo, 2016; BBC News, 2015).

Available records have shown that Boko Haram does not have high-level financing structures like other terrorist organizations (ISIL, Al-Qa'ida and the Taliban). The group has historically relied largely on erstwhile operations to fund its activities. This further shows that Boko Haram has a decentralized network with local commanders required to generate revenue to fund their own activities. Some of the most common techniques employed by the group to raise fund include abduction of persons for ransoms, kidnapping, extortion of various businesses, bank and armed robberies and smuggling. In addition, the group has also been known to raise funds by utilizing a network of alliances with other terrorist organizations including receiving funding from Al-Qa'ida in the Land of Islamic Maghreb (AQIM) (Kingsley, Johnson-Rokosu \& Olanrewaju, 2015).

Mass kidnapping of foreigners and civilians for ransom has over the years proven to be a profitable method of fundraising (GTI, 2017). In fact, reports indicate that Boko Haram has a specialized kidnapping task focuses on the abduction of politicians, business people, foreigners, traditional rulers and civil servants with the intention of trading them for large sums of money or for the release of captured and/or imprisoned Boko Haram militants (Kingsley et al., 2015) for example, in 2013, Boko Haram was paid US\$3 million (about N480 million at the prevailing exchange rates then) in ransom to release a French family of seven persons (GTI, 2017).

\section{LITERATURE REVIEW}

\section{The Concept of Terrorism}

Terrorism has no single global definition. Agara (2015) has defined it as "propaganda of the deed" or "propaganda by deed". Adora the UN office for Drugs and Crime Prevention in 1992 defines terrorism as "an anxiety-inspiring method of repeated violent action, employed by (semi-) clandestine individuals, group or state actors, for idiosyncratic, criminal or political reasons, whereby - in contrasts to assassination, the direct targets of violence are not the main targets (Adora, 2010; Elden, 2014). Another important definition of terrorism was given by African Union (AU) in article 1 (3) as: "any act which is a violation of the criminal laws of a state party and which may endanger the life, physical integrity or freedom of, or cause serious injury or death to any person, any number or group of persons or causes or may cause damage to public or private property, natural resources, environmental or cultural heritage (Oyeniyi, 2010). 
The Global Terrorism Index (GTI, 2016), defines terrorism as "the threatened or actual use of illegal force and violence by a non-state actor to attain a political, economic, religious, or social goal through fear, coercion, or intimidation." According to this definition, terrorism it not merely the physical act of carrying out an attack, but also the psychological effect it has on a society for many years afterwards. It has been described as a "highly concentrated form of violence, mostly committed in a small number of countries and by a small number of groups" (pp. 3, 17).

Traditionally, the execution of acts of terrorism depend on tactics aimed at creating constant fear in society, say, surprise, concealment, deception, stealth and conspiracy. Anaedozie enumerated that most known objectives of terrorists include provocation, indoctrination, radicalization, media propaganda, insurrection, force, intimidation, creation of chaos or societal dislocation, discrediting or destroying a government; crippling economy, destroying property and spreading fear for global attention (Anaedozie, 2016; Barkindo, 2013). The Global Terrorism Index 2016 report has identified five countries have been identified as suffering the highest impact from terrorism, namely Iraq, Afghanistan, Nigeria, Pakistan and Syria. In 2015, 72\% of all terrorism-related deaths occurred in those countries and, surprisingly, only four terror groups, namely ISIS, Boko Haram, the Taliban and AI-Qaida were responsible for a whopping $74 \%$ of all the deaths (GTI, 2016).

Out of the myriads of tactics and strategies of insurgency available, terrorism has been shown to be the preferred choice, especially because of its psychological effects. Nearly two decades since the wake of the $21^{\text {st }}$ Century, terrorism (especially on religious or faith divides) is increasingly becoming appealing to youth irrespective of their nationality and gender. The media are replete with reports about young men and women seeking to join terrorist groups folds (mostly from EU countries like Britain, France, Germany, Italy and Spain as well as the US and Australia), or are being abducted and indoctrinated (especially in Sub-Saharan countries such as Nigeria, Niger, Cameroun, Chad, Mali and Somalia) (Elden, 2014; Graaf, 1982; Stephens, 2010).

\section{Factors Influencing Terrorism}

Globally, terrorism has had devastating social, economic, cultural and political effects in societies across the world, mostly in countries colonized during the $20^{\text {th }}$ Century. A research study conducted in the US by Stephens (2010) suggests that there is a correlation between a country's colonial history and terrorism. The study further reveals that colonial history linked with ethnolinguistic, political and economic assimilative tendencies are significantly associated with circumstances that are more likely to breed terrorism and terrorism-related conflicts. This suggest that there are enduring adverse effects of colonialism give rise to ethnic, political and economic conflicts which lead to guerrilla attacks (insurgency) and ultimately, terrorism (see Figure 1 ) even when the ethnic groups are unified linguistically and politically. This is because, as Stephens (2010) notes, "the colonizers often altered traditional ethnic relationships and power structures" (p. 56). 


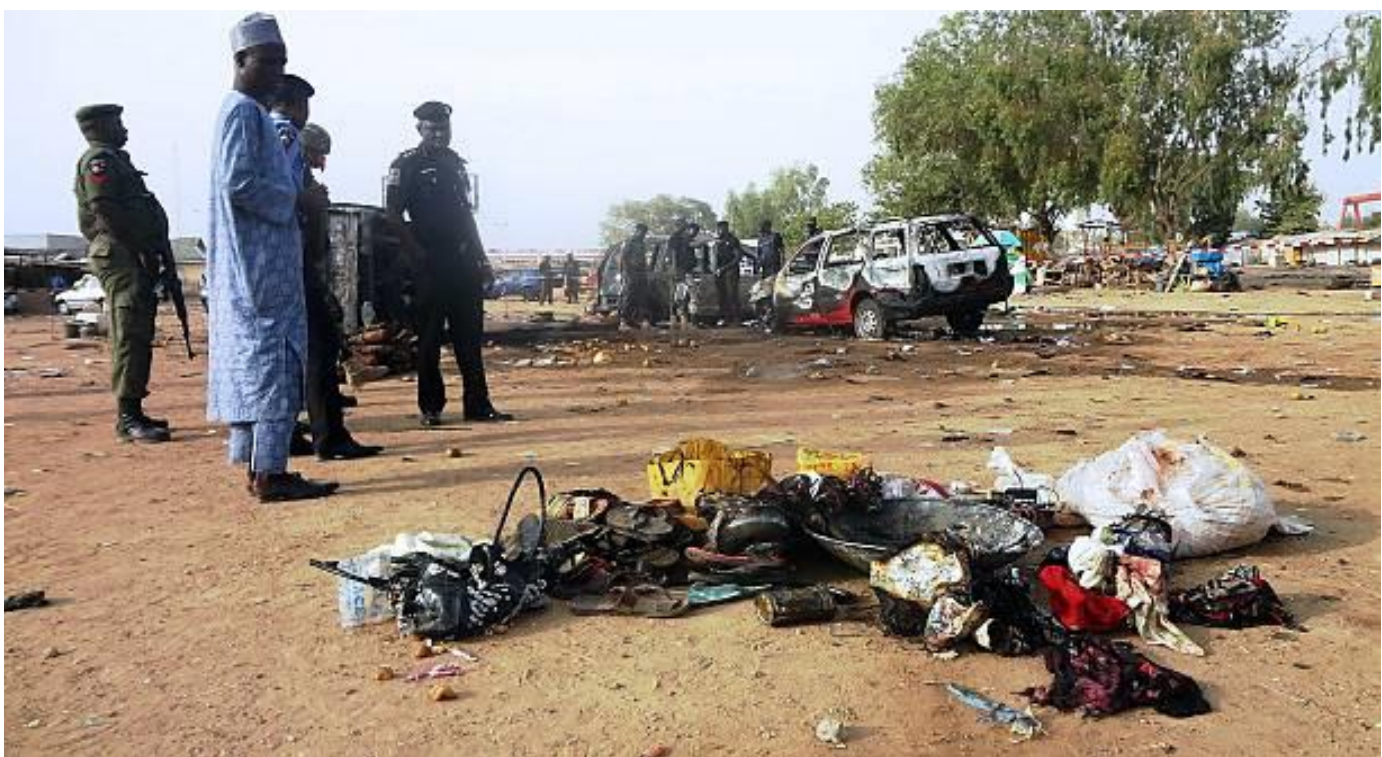

Figure 1: Nigerian Police bomb experts inspect the scene of a suicide bomb attack (Source: Getty Images)

Therefore, even though the Boko Haram's ideological prohibition of Western education and Western values were premised on so-called Islamic doctrine, by all means, they are fundamentally rooted in the British colonialists' alteration of the nation's ethnic relationships and political structure. In a nut shell, colonialism can be the root cause of the present breed of faith-based or religious terrorism raging across the world, especially in SubSaharan Africa, the Middle East and North Africa (MENA) and South Asia. So, there has been collision between the social, cultural, political and economic values imported by colonial masters and the indigenous ones; thus, over the decades they ultimately breed militancy and terrorism (Abdulazeez, 2016; Barkindo, 2013; Khawaja, 2010; Onyeniyi, 2010).

Another school of thought links terrorism to factors associated with politics. In his famous online article entitled, The International Terrorist Conspiracy Gwynne Dyer (2006, June 3, online) that:

Terrorism is a political technique, not an ideology and any group willing to use violence in pursuit of its political goals may resort to it.... There are leftwing terrorists and right-wing terrorists; national terrorist and international terrorist; Christian, Muslim, Jewish, Hindu, Buddhist and atheist terrorists.

This argument is supported in the 2016 Global Terrorism Index report, which succinctly identifies two distinct factors associated with politics that drive terrorism, namely state-backed political violence and the presence of a conflict. A vast majority (93\%) of the terrorist activity that occurred between 1989 and 2014 have been shown to have occurred in countries that human rights are bluntly violated, e.g., imprisonment without trial, torture, extrajudicial killing and have high tendencies of perpetrating state-sponsored terrorism. Similarly, countries already engaged in some forms of local (internal) or international conflicts have been shown to have over $90 \%$ fatalities associated with terrorism. Then, why only about $0.5 \%$ of all terrorist attacks took place in countries that did not suffer from a political conflict or violence (GTI, 2016)? 
Statistically significant political factors that have correlates with terrorism are often viewed from the development status (developed or developing) of a country. In developed and emerging economies (e.g., the Organization of Economic Cooperation for Development, OECD countries like Britain, France, Germany, Italy and Turkey), OECD member countries with poorer performance on socio-economic factors that can reinforce some of the wellknown drivers of radicalization and extremism such as unemployment among young persons, level criminality, access to weapons, militancy and apathy in the electoral process have been found to be statistically significant correlates of terrorism. For example, of the 34 OECD member countries, 21 experienced at least one terrorist attack between 2015 and 2016, with most fatalities occurring in France and Turkey (GTI, 2017).

\section{The Role of Media in Counterterrorism and Restoration of Peace}

Media publicity and accessibility to the Internet have been consistently shown to influence acts of terrorism. Many of the known terrorist groups in the world have at least own an online personal account mostly on porous social network sites like Twitter and YouTube, which they use to spread propaganda. For example, to demonstrate the degree to which ISIS values media publicity and power of the Internet, the group has gone to the extent of publishing its own sophisticated propaganda online magazine titled Dabiq, for recruitment and proselytization, which was first published on 5 July 2014 in several languages including English (Wikipedia, 2017). The Boko Haram group is known for releasing most of its online propaganda videos on the Internet (YouTube) and online news media. Sometimes the group's videos and messages are broadcast on Al-Jazeera TV and Sahara Reporters online news sites (Mu'azu, 2015).

Furthermore, whenever terrorism is discussed, media and media-related issues must inevitably be considered especially in this era of globalization. Media are the channels which connect and bind the various segments of the human society together. From the era of mass communication, which is symbolically based on a 'one-to-all' basis of information dissemination to the present age of information and communication technology (ICT), which is largely based on a 'from-all-to-all' technique information, communication and publicity have always been some of the key functions of the media make them inextricably part and parcel of society (Baran \& Davis, 2012; Moorthy, Benny, \& Gill, 2018).

Realizing these characteristics of the media, terrorist organizations and groups have always overtly or covertly sought to exploit the motivations media could offer to their nefarious acts. For instance, Pate and Idris (2017) have shown that in its earlier days, Boko Haram members used to invite journalists to cover their terror activities; "indeed", according to Mu'azu (2015) cited in Pate and Idris (2017), "the Boko Haram did trace how they were covered by the media because they [Boko Haram] were dictating how the group should be reported" (p. 160). In fact, just like terrorists are terrorists because they weaken the loose ends of the chain that holds the society using the power of fear, so media are watchdog of the society because through thick and thin they bear the risks and costs of keeping the society informed of occurrences within it (Pate \& Idris, 2017).

This, though, has created a maze of ambiguity within academic circles with some quarters critiquing the media of being a complicit rather than explicit in the counterterrorism campaign. Asogwa, lyere and Attah (2012) cited in Schmid and de Graaf (1982) belong in the school of thought that exonerates the media from being complicit in terrorism where they stress that, "the media are not simply gatekeepers, neutral or 
complicit with either state or terrorists, but rather are active agents in the process of the construction of information" (p. 178). This underscores the significant role both the mass media and new media of communication can be effectively employed in the anti-Boko Haram campaign (Mu'azu, 2015; Pate \& Hamza, 2017).

Further, outlining the correlation between terrorism and media, Ibrahim and Hassan (2017) demonstrate that terrorist groups do rely on the 'free' publicity the media provide them with through, e.g., news reporting and user-generated contents shared on social media and blog spots online. Hence, just like religious, political and socio-economic factors have been shown to significant correlate with terrorism, we confidently believe that media publicity directly affects acts of terrorism, and public opinion which is the by-product of media publicity in society both directly and indirectly influences the effect of media publicity on terrorism (see Figure 2).

The symbolic symbiotic relationship between the media and terrorism may be a funny one. Terrorists possess an overwhelming influence of attracting global attention while the media possess a wealth of audiences. There is no doubt that the media possess a larger public than terrorists do; and this public who looks onto the media for proper information dissemination that would lead to national security and meaningful developments is indispensable to the existence of the media. By and large, terrorism receives greater degree of coverage from the media (Othman \& Mat, 2018) (especially global media organizations such as the BBC and $\mathrm{CCN}$ ) more than do conflict resolution, peace-building and developmental achievements in less developed countries.

Indeed, to perform their duty of being the watchdogs of the society and information dissemination, the media do not need the terrorists, but the terrorists would certainly not exist in the minds of many people without the media publicity of their activities, thus suggesting a linear relationship path (Asogwa et al., 2012; Bilgen, 2012). Arguably, the symbiotic relationship between the media and terrorism is rather circumstantial and temporary. This is so, because terrorism is more likely to cease with the absence of the factors that were responsible for its occurrence (Schmid \& de Graaf, 2012) in the society, unlike if the relationship were permanently continuous, or circular. However, due to the guerrilla tactic nature of the Boko Haram terrorism, conventional mass media may need to be complemented with the application of emerging conflict management technologies such as human-wearable digital microchip systems. The next section discusses these issues. 


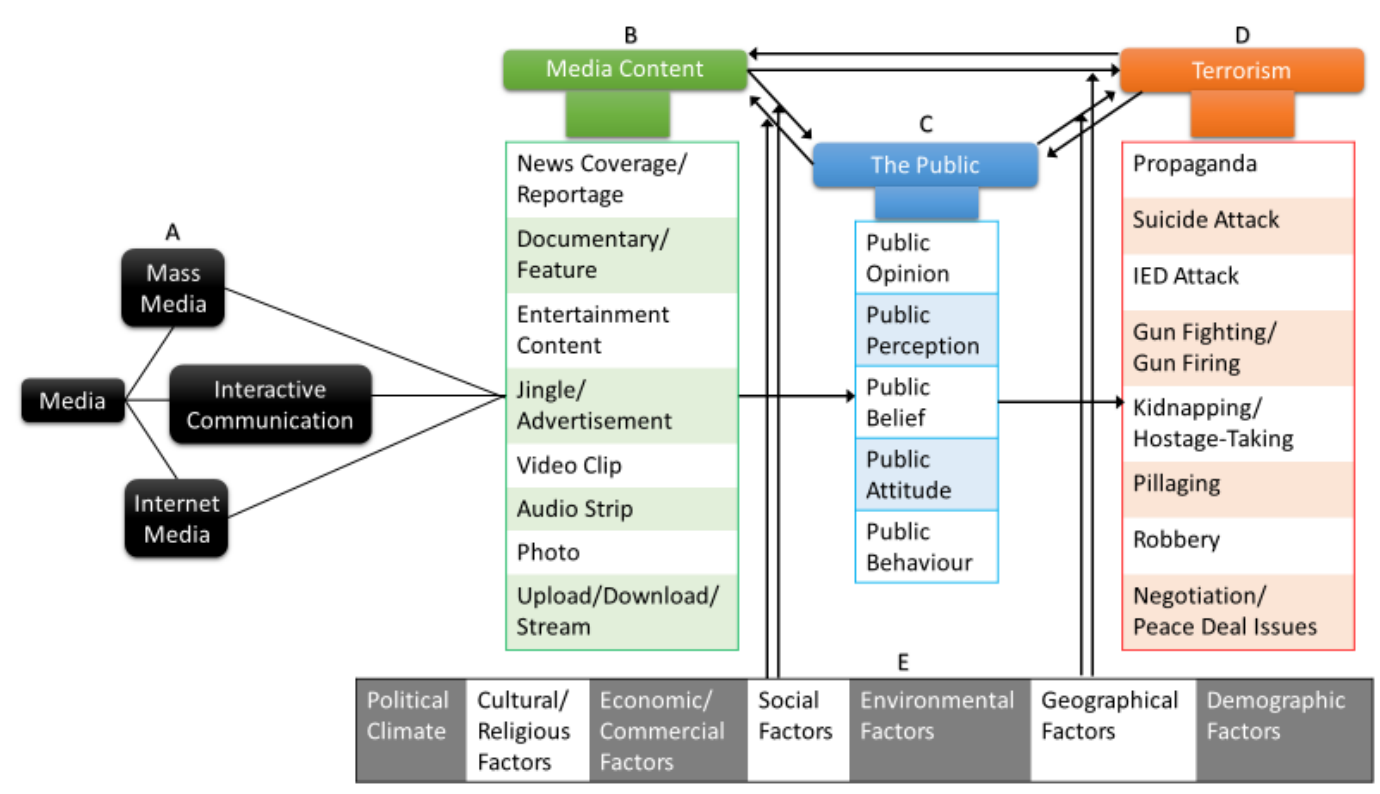

Figure 2: A diagrammatical representation of the media-terrorism dynamics

(Source: Ibrahim \& Hassan, 2017, p. 32).

Note: This diagram is divided into four dimensions, namely A: Media categories; B: Types of media content; C: The publics (media content consumers) and the impacts of the media content on them; $D$ : Terrorism and issues surrounding it; E: Factors driving terrorism

The Use of Human-Wearable Microchip Digital Media Technology in Conflict Management Advances in technology are unearthing more and more secrets of the unfathomable uses and applications of information and communication technology (ICT) for social and economic development. For instance, the use of digital wearables in their various forms (e.g., digital wrist band, e-bracelets, etc.) is an 'emerging technology' field of research that has a lot of potential (Awan, Memon, \& Bhutto, 2017). Digital tracking technology has been identified as one of the most remarkable revolutionary technologies in use nowadays. Tracing the history of the application object tracking technology from post-World War II to its use in the 21st Century, the amazing impact of tracking technology becomes evident (Covacio, 2003; Rodriguez, 2019).

Given its novelty, the use of wearables and other similar sensor technologies in both humans and animals (Arya \& Bilandi, 2007; Ramli \& Ahmad, 2011) is categorized as an emerging technology. Wearabes are applied in body area networks (BAN) and extensive systems to "provide efficient and reliable services." (Awan et al., 2017, p. 377). Currently, the use of WBAN (Ramli \& Ahmad, 2011) in security issues is attracting research attention. However, a number of research directions (Michael, Michael, \& Ip, 2008) have applied BAN systems in health issues for the monitoring of patients (Fouad, 2014; Kaiser \& Sarrafzadeh, 2010). Apart from WBAN, radio frequency identification (RFID) is another technology with great adoption potential that is being used. RFID technology is based on wireless communication system, which enables users to exceptionally identify tagged humans, anaimals or objects (Haggerty \& Trottier, 2013). RFID technology relies on two physical components namely, readers and tags to complete it task. The readers perform the task of gathering information from the tags. The tags are primarily used to track individual humans, animals or objects. The data from the tag to a reader are transfered using radio waves (Awan et al., 2017). As noted by Rodriguez (2019, p. 1583) and Landt (2005, online) RFID is 
increasingly becoming "an integral part of our life." and ubiquitous in applications nowadays.

The use of RFID applications are reported in commerce, where retailers use it in tracking commodities such as apparel (Yao, Schmitz, \& Warren, 2005); in autombile industry where drivers use it in automating on-road payments (Lin, Jan, Ko, Chen, Wong \& Jan, 2004); in hospitals where managements use it in minimizing loss of equipment (Golmie, Cypher, \& Rebala, 2005); in business firms and corporations where managers use it in enhancing "their supply-chain management" (Awan et al., 2017, p. 1583; Arya \& Bilandi, 2007) and, even in sports where, e.g., golfers use it in tracking lost golf balls.7 Rodriguez noted that nowadays, the application of RFID microchips is no longer restricted to inanimate objects such as goods and commodities. With the innovative application of geopositioning system (GPS) technology RFID systems are can be implanted subcutaneously, into pets, children and even employees in an organizational context (Awan et al., 2017; Kaiser \& Sarafzadeh, 2010). Although quite limited literature exists on the appication of microchip digital wearable systems such as RFID and WBAN in humans living in conflict zones for security and humanitarian aid purposes (Saleem, Ullah \& Kwak, 2011), the technology has a potential to impact humanitarian aid efforts toward providing safety for people living in armed conflict zones and for tracking kidnapped victims, for example. Hence, this paper proposes the application of a modified Laswell's model of communication in manufacturing emerging tracking systems such as RFID and WBAN for use in humanitarian contexts.

\section{Application of Mass Communication Theory Toward Digitization of the De-Bokoharamization Campaign}

Putting the historical background of Boko Haram, the number of people it has killed and the level of damage it has caused vis-à-vis those of other terror groups (such as Al-Shabab, and ISIL), one can confidently say that within the 10 years of its terrorism the group has proven to the world that it is a very hard nut to crack. So far, nearly all critical conventional means and strategies of counterterrorism have been employed in the de-Bokoharamization campaign with moderately significant successes, but the group is still able to carry out successful attacks and small-scale kidnappings. Like most other terror groups, Boko Haram uses guerilla war tactics - and guerilla warfare is an unconventional kind of war, which makes it very difficult to contend (Abdulazeez, 2016; Crelinsten, 2017).

Generally, however, when the pre-2015 and post-2015 Boko Haram terrorism campaigns are examined, one will realize that the Buhari Government has achieved tremendous success, at least by dislodging the group from their long-time base in the Sambisa Forest, numerically decimating them and tactically weakening them (Premium Times, 2015; Warner \& Matfess, 2017). To further lend a helping hand to the Government in the de-Bokoharamization campaign especially in a media-related context, this intellectual brainstorming ideation is needed.

Our modest intellectual contribution toward the de-Bokoharamization campaign focuses on the application of the rudiments of Harold Laswell's (1948) model of communication; and it is not intended to be a panacea to the insurgency rather, this model, is intended to be applied in the development of an emergency incident data gathering system (EIDGS) in the form of wearable devices, or simply, wearables (e.g., digital bracelets, or e-bracelets) such a wristbands, armbands or neckbands. It should be based on global 
positioning system (GPS) service or a special application should be developed for that purpose.

We borrowed the idea of experimenting the electronic safety wearables in the deBokoharamization campaign from the Saudi Kingdom innovative adoption of hi-tech safety measures for the Hajj pilgrims from 2016 following a massive stampede (which is one of the worst tragedies in the history of the Hajj pilgrimage) that occurred on September 24, 2015, with reports indicating that at least 2,297 pilgrims died with many of the victims unidentified (News18.com, 2016). Hence, this paper recommends that people living in Boko Haram-infested areas, or people who are highly susceptible to perceived Boko Haram attacks should be encouraged to wear the wearables or e-bracelets. It is expected that if this hi-tech safety measure is adopted and strategically applied (used), will help authorities provide timely succor to the victims and the security forces will be able to monitor, study the guerrilla-warfare behavior of the insurgents, trace their locations and do the needful (Moorthy et al., 2018). In addition, this hi-tech safety measure can help the troops at the warfront to trace the locations of hostages that wear the e-bracelets. This is a key reason that the wearables should be designed as miniature bracelets or wrist watches so that Boko Haram fighters are not able to easily identity the wearable and cause more harm or kill the victim. The digital bracelets should be designed as waterproof, shockproof and pressure resistant.

The model is linear, and is based on the following five questions: (i) who (said), (ii) says what, (iii) in whch channel, (iv) to whom, (v) with what effect? A little modification to the model will yield the following five constructs (dimensions): (i) Source (S), (ii) Message (M), (iii) Channel (C), (iv) Receiver (R) and (v) Feedback (F) (SMCRF). Source produces the message to be communicated to the destination. Message is the concept, information, communication or statement (audio, visual, audio-visual, written) that is sent to the recipient (destination). Channel is the medium used to transmit or communicate the message to the destination. Receiver or destination is the person or system for whom the message is intended. Feedback is the reaction of the destination back to the source, which could be direct or indirect. The feedback may be affected by time, space, logistics, quality of data (message) signals received, magnitude of the incident (based on the data analysis at the cybernetic center), media support, social support and the Government's determination. These five constructs or dimensions are operationalized as follows.

First, Source: in the context of the present discourse, Source refers to the person sending the signals, that is, the attacker (Boko Haram) and the victim (e.g., a child, a farmer, etc.). Second, Message: regarding the attacker (Boko Haram), the message which the wearable captures may be rattles of gun shots or booms of improvised explosive devices (IEDs); while in the part of the victim the signal may be screams and yells for help or fleeing to safety movements, etc. Third, Channel: largely, only one channel is involved in this model, and it is the IEDGS wearable which the hypothetical victim (e.g., a child, woman, farmer, trader, etc.) wears in the form of wristband or neckband. The IEDGS wearable captures the signals and transmits them using GPS service or any special digital service to the Receiver. Fourth, Receiver: a cybernetic digital signal reception and processing center that is constructed for this purpose should be the destination of the signals. The center should be manned by cybersecurity experts from the military, or the State Security Service (SSS), or both. The data which are received in the form of digital signals are processed, interpreted and communicated to the appropriate government department or unit for subsequent 
strategic action, e.g., military/security (feedback) action. Fifth, Feedback: after deliberate study and analysis of the data, the feedback may largely involve the mass and social media in community mobilization, public enlightenment in addition to strategic military/intelligence activities to trace and eliminate/capture the dodgy guerillas (Boko Haram) and/or rescue hostages and surviving victims that may be there. See Figure 3 for a graphical sketch of the modified model.

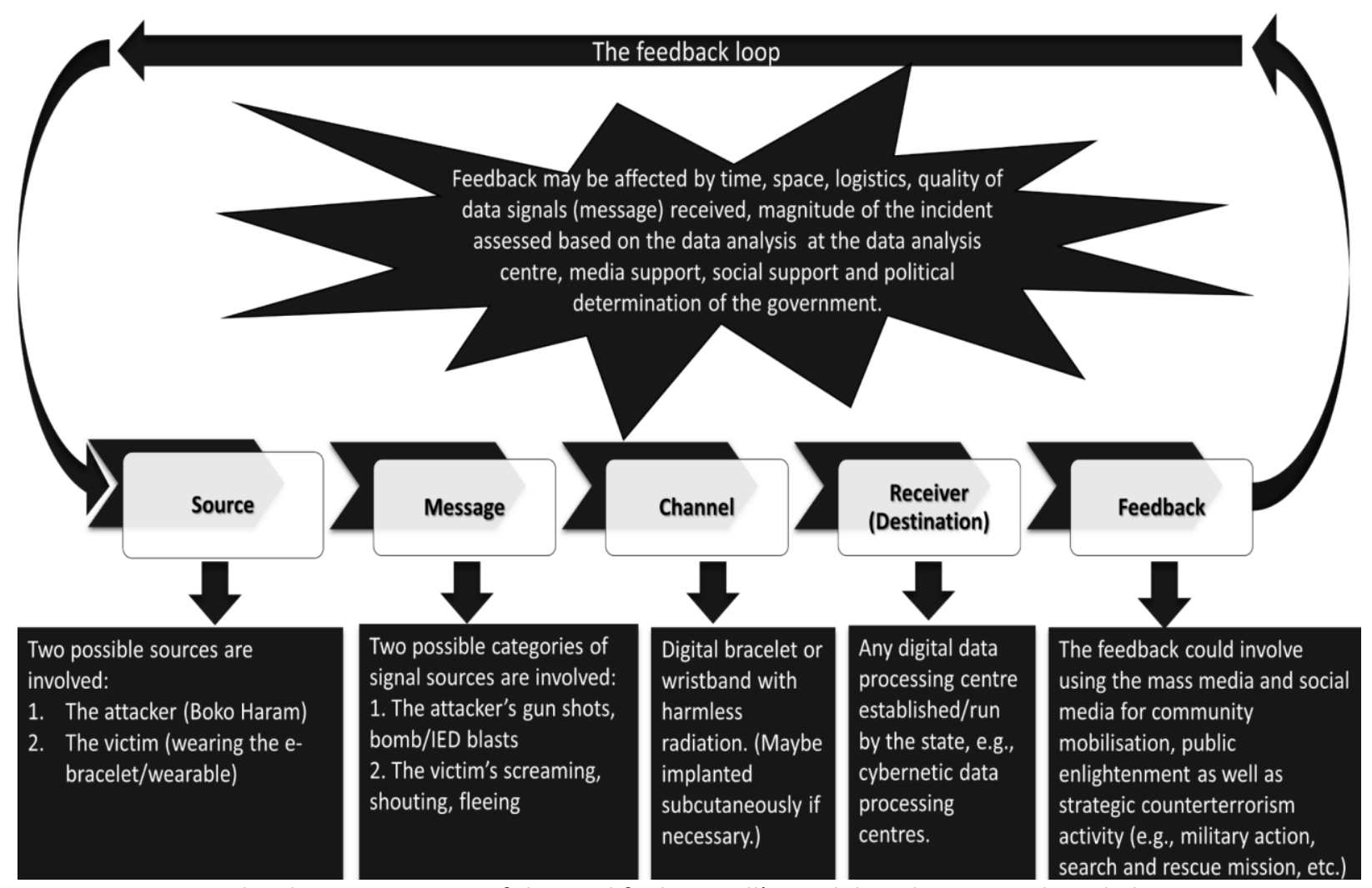

Figure 3: A graphical representation of the modified Laswell's Model application in de-Bokoharamization campaign using digital wearables (Source: Authors)

Given the nature of Boko Haram's attacks (guerilla tactics, suicide bombing, including kidnapping), the nature of most of the people affected by the attacks (children, women, the elderly, farmers, merchants) and the nature of the environment in which most of the attacks (and kidnapping) are carried out (countryside, rural communities, village markets), we believe that adopting that model in the anti-terrorism campaign will go a long way in proffering practicable solution to the monstrous insurgency. The Government, the military and other critical stakeholders should collaborate with technology developers.

Nations cannot develop in an atmosphere devoid of peace. Peace and security of life are pre-requisite for development of any kind. Absence of peace, security and the presence of conflict in a country discourage people, governments and organizations to invest in a country. For example, conflict-ridden countries like Afghanistan, Iraq, Nigeria, Israel, Libya and Syria would hardly attract reasonable business investments or tourists (lyere, 2006). These countries share something in common: governments rarely devote public resources for constructive development projects capable of lifting the living standard of the people. With loose national security, high rate of illiteracy and youth unemployment, angry youth easily take to up arms against the state, something that if left poorly tackled often leads to 
insurgency and terrorism (Istadiyantha, 2018); the Niger Delta crisis which has seriously affected the Nigerian economy and Boko Haram insurgency are good examples. Decrying human indulgence in anti-development acts that often cause unquantifiable destruction of life and property in society, Asogwa et al. (2012) posits:

\begin{abstract}
Human beings are highly endowed with the capability for development. Each decade gives birth to new developments to make the world a peaceful and enjoyable place for all. Sad enough, human beings themselves occasionally bring about massive destructions of what it took many years to build. By this act of barbarism mankind tends to slow down the wheel of progress (p. 180).
\end{abstract}

Socio-economic development in such places is put on hold with much attention and resources being diverted to finding solution to Boko Haram insurgency. However, with the introduction of amnesty and peace corridor, a lot of peace has returned to many parts of the North-east. Generally, the media play a pivotal role in the matrix of terrorism, insurgency, political violence and peace. The society puts the media into positions where they can magnify or minimize these kinds of acts and their perpetrators or provide coverage that avoids either one of those extremes (Istadiyantha, 2018; Naos, 2002). The media are expected to actively and proactively play the roles mentioned in the paragraphs below to minimize both the actual and virtual impacts (Bilgen, 2012) of terrorism.

The Government should focus on the creation and strategic dissemination of counter-narrative messages aimed at dehumanizing the Boko Haram ideology of religious extremism over carefully selected media outlets. Even media framing, community policing such as that provided by local young men popularly known as Civilian JTF (CJTF) and vigilante groups, community outreach and public enlightenment and education, which involves the dissemination of purposefully designed messages to audiences have been shown to be effective tools for counterinsurgency.

Looking at the alarming rate of illiteracy and poverty in the North, an effective, sustainable and development-oriented counterinsurgency activity will certainly involve addressing the economic, educational, material and psychological concerns that render individuals vulnerable to recruitment by the group by creating alternative motivation and incentive structures to dissuade people from adopting violence and extremism as ways of seeking redress to their grievances. The role of the media (traditional, conventional and new information and communication technologies, ICTs) here is to design messages aimed at peace-making by encouraging dialogue with the insurgents, which can serve as a salient function in challenging and even refuting undesired perceptions (Crelinsten, 2017; Ibrahim \& Hassan, 2017).

Therefore, the Nigerian Government should strengthen efforts to maintain public trust and public confidence, which serve as critical success drivers in any counterterrorism action. The evidence of this can be seen when a comparison is made between the globally acknowledged remarkable successes achieved in the counterinsurgency during the Buhari Administration, which enjoys massive public trust and confidence vis-à-vis the publicly decried failures recorded by the Jonathan Administration (Abdulazeez, 2016; Bloom, Horgan, \& Winter, 2016) which had lost not only the public trust and confidence of the country's citizens (Salaam, 2012) but those of the international community as well (Ogunnubi, Onapajo, \& Isike, 2016), consequent upon which the insurgents became 
stronger to the extent of conquering several territories (Celso, 2015) in the North-eastern part of the country.

Public confidence and trust can be maintained both before and after the terrorist attacks if the media are employed to enlighten and educate the public about the nature and extent of the Boko Haram threat and propaganda, which it often spreads using video clips through online social networks, particularly YouTube (Antwi-Boateng, 2017) and occasionally, via leaflets (Forest, 2012), especially in its earlier days. Promoting peace and public awareness without fueling insecurity, apathy, intolerance and hatred is an essential element in the de-Bokoharamization campaign. Hence, counter-terrorism campaign messages for peace should have the right combination of not only seeking for the condemnation and dehumanization of the terrorists and their activities but also seeking protection for the vulnerable groups, e.g., women and children.

\section{CONCLUSION}

Although the development and adoption of digital microchip tracking systems in humans are still being investigated, their potential for application in providing safety for people living in armed conflict zones cannot be doubted as highlighted earlier in the review of literature section. The literature demonstrates that the media are always employed to wage psychological warfare on conflict targets through propaganda, heart-and-mind conquest campaigns, de-radicalization and reconciliatory efforts of providing incentives for extremists and insurgents to abandon violence and seek non-violence ways of seeking redress for their grievances. For instance, counter-narratives have been shown to be effective in this regard (Crelinsten, 2017). Particularly, counter-narrative messages that foster inter-Islamic sects understanding can tremendously undermine the propaganda and extremist ideology of Boko Haram which promote hatred among different Islamic sects by labelling other individuals and groups that do not follow their ideology as infidels (Ngige et al., 2016). It is believed that the recruitment and radicalization processes for all suicide bombers are excruciatingly emotional (Bouzar, 2016). Therefore, it is advisable that for any deradicalization, or de-Bokoharamization campaign to be effective and for peace to reign in the society, counter-narratives also must be emotional as well.

The Government and key stakeholders should pull resources and effort together to render the society a less breeding ground for extremism and terrorism. Peace is an essential element in nation-building. Peace must be maintained at all cost; in fact, no amount of resources expended can be too much for the maintenance of peace and harmony in any society. We believe that if factors that bring about mass kidnapping by terrorist groups are smoked out from the society, the environment would cease becoming a breeding ground for terrorism in general, and suicide terrorism in particular. An individual child might be used so cruelly, but not large cadres of children. Deaths from suicide terrorism have been increasing. In fact, the actual statistical evidence for the number of suicide attacks carried out by women and children is just beginning to be appreciably documented, but the trend the attack is clear; it is a horrible development in a race that the world must not afford to lose. Finally, it is recommended that future research should explore the practical applicability of human-wearable digital media technology as an alternative means of managing armed conflict and human vulnerabilities. 


\section{BIODATA}

Adamkolo Mohammed Ibrahim is a lecturer at the Department of Mass Communication, University of Maiduguri PMB 1069, Borno State, Nigeria. Currently, in addition to lecturing, he is a regular research manuscripts reviewer at the famous Elsevier's journal Computers in Human Behaviour (CHB). Email: adamkolo@unimaid.edu.ng

Mohammed Gujbawu, PhD, is a Professor at the Department of Mass Communication, University of Maiduguri, Nigeria. He is also a former Sub-Dean of the Faculty of Social Sciences of the University. Email: gujjba1966@gmail.com

Nassir Abba-Aji, PhD, is a senior lecturer at the Department of Mass Communication, University of Maiduguri, Nigeria, and the current Head of the Department. Email: click2nass@unimaid.edu.ng 


\section{REFERENCES}

Abdulazeez, M. A. (2016). The inadequacies of exclusive military action: Countering Boko Haram's terrorism with alternative approaches. In Selected Papers: Terrorism Experts Conference (TEC) 2016 (pp. 26-60). Brussels: NAT.

Adora, C. U. (2010). Renewing the face of counter terrorism for global peace: The challenges for theater artists in Nigeria. Jos Journal of Humanities, 4(1), 103-114.

Agara, T. (2015). Gendering terrorism: Women, gender, terrorism and suicide bombers. International Journal of Humanities and Social Science, 5(6/1), 115-125.

Aljazeera (2019). 10 civilians killed in suspected Boko Haram attack in Niger town. Aljazeera, March 27. Retrieved May 31, 2019 from https://www.aljazeera.com/amp/news/2019/03/10-civilians-killed-suspected-bokoharam-attack-niger-town-190327144532205.html

Anaedozie, F. (2016). Has the emergence of female suicide bombers in Nigeria depicted the exploitation of feminine vulnerability? A critical appraisal of Boko Haram's female suicide bombers in Nigeria. International Journal of Innovative Research and Development, 15(3), 127-227.

Antwi-Boateng, O. (2017). Boko Haram and the Islamic State: A tale of two terrors. Conflict Studies Quarterly, 18, 20-39.

Arya, S., \& Bilandi, N. (2007). A review: Wireless body area networks for health care. Int. J. Innov. Res. Comput. Commun. Eng., 3297(4), 134-167.

Assanvo, W., Abatan, J. E., \& Sawadogo, W. A. (2016). Assessing the Multinational Joint Task Force against Boko Haram. West Africa Report, (19). Retrieved December 21, 2016 from https://issafrica.s3.amazonaws.com/site/uploads/war19.pdf

Asogwa, C. E., Iyere, J. I., \& Attah, C. O. (2012). The mass media reportage of crimes and terrorists' activities: The Nigerian experience. Asian Culture and History, 4(2), 175181.

Awan, J. H., Memon, N. A., \& Bhutto, Z. (2017). Conceptual model for WWBAN (wearable wireless body area network). International Journal of Advanced Computer Science and Applications, 8(1), 377-381.

Baran, S. J., \& Davis, D. K. (2012). Mass communication theory: Foundations, ferment, and future (6th ed., p. 25). Boston: Cengage Learning.

Barkindo, A. (2013). Join the Caravan: The ideology of political authority in Islam, from Ibn Taimiyya to Boko Haram in North East Nigeria. Perspectives on Terrorism, 7(3), 30-43.

BBC News. (2015, January 30). Boko Haram crisis: African Union backs regional force of 7,500 troops.

Bilgen, A. (2012, July). Terrorism and the media: A dangerous symbiosis. E-International Relations, the George Washington University, USA.

Bloom, M., Horgan, J., \& Winter, C. (2016, February). Depictions of children and youth in the Islamic State's martyrdom propaganda, 2015-2016. CTC Sentinel, 9(2), 29-32.

Bouzar, D. (2016 May). Rescue mission: Freeing young recruits from the grip of ISIS. Scientific American Mind, 27(3), 41-43.

Celso, A. N. (2015). The Islamic State and Boko Haram: Fifth wave jihadist terror groups. Orbis, 59(2), 249-268.

Crelinsten, R. (2017). A comprehensive approach to counterterrorism: An overview. In Selected papers: Terrorism Experts Conference (TEC) 2016 (pp. 8-25). Brussels: NATO. 
CNN. (2015, January 12). 2,000 feared killed in 'deadliest' Boko Haram attack in Nigeria. (Reporters: Amina Abubakar and Faith Karimi). Retrieved August 19, 2017 from http://www.cnn.com/2015/01/09/africa/boko-haram-violence/

Council on Foreign Relations (CFR). (2016a). Nigeria security tracker. Retrieved October 17, 2017 from http://www.cfr.org/nigeria/nigeria-security-tracker/p29483

Council on Foreign Relations (CFR). (2016b). What makes Boko Haram run? (Author: John Campbell). Retrieved May 5, 2018 from http://www.cfr.org/nigeria/makes-bokoharam-run/p37838

Council on Foreign Relations (CFR). (2015). Boko Haram. (Authors: Mohammed Aly Sergie, and Toni Johnson). Retrieved March 5, 2015 from http://www.cfr.org/nigeria/bokoharam/p25739

Council on Foreign Relations (CFR). (2012, November 15). Nigeria security tracker: Mapping violence in Nigeria.

Covacio, S. (2003). Technological problems associated with subcutaneous microchips for human identification (SMHId). In InSITE June 2003. Informing Science, 843-853.

Croteau, D., \& Hoynes, W. (2019). Media/society: Industries, images and audiences (6th ed.). New Delhi: Sage Publications.

Dyer, G. (2006). The international terrorist conspiracy. Retrieved October 29, 2018 from http://gwynnedyer.com/2006/the-international-terrorist-conspiracy/

Elden, S. (2014). The geopolitics of Boko Haram and Nigeria's 'war on terror'. The Geographical Journal, 180(4), 414-425.

Forest, J. J. F. (2012). Confronting the terrorism of Boko Haram in Nigeria. Joint special operations university (JSOU) report 12-5. MacDill, Fl.: The JSOU Press.

Fouad, H. (2014). Patient-oriented web telemedicine system for health monitoring. J. Commun. Comput., 11, 168-178.

Golmie, N., Cypher, D., \& Rebala, O. (2005). Performance analysis of low rate wireless technologies for medical applications. Comput. Commun., 28(10),1266-275.

Google image. Retrieved 19 February 2018 from https://goo.gl/images/3QiD8B

Graaf, J. (1982). Violence as communication: Insurgent terrorism and the Western news media (pp. 178). London: Sage.

GTI. (2017). Global terrorism index: Measuring and understanding the impact of terrorism (pp. 85). New York: Institute for Economics and Peace.

GTI. (2016). Global terrorism index: Measuring and understanding the impact of terrorism (pp. 3 \& 17). New York: Institute for Economics and Peace.

Haggerty, K. D., \& Trottier, D. (2013). Surveillance and/of nature: Monitoring beyond the human. Society and Animals, 1-20. doi: 10.1163/15685306-12341304

Ibrahim, A. M., \& Hassan, M. S. (2017). Media versus Boko Haram: Proposing the adoption and use of cyber technology by terror groups model for counterinsurgency (pp. 32). Beau-Bassin, Mauritius: Lambert Academic Publishers.

Istadiyantha, H. A. (2018). Revealing the propaganda of communication between the Islamic fundamentalism activists of the Middle East and Indonesia. Jurnal Komunikasi: Malaysian Journal of Communication, 34(2), 137-151. doi: 10.17576/JKMJC-20183402-09

Iyere, J. (2006). Religious management as a tool for global peace. In D. Stinton (Ed.), The arts, man and globalization: Trends, issues and problems (pp. 377-385). Accra North: Deocraft Communications. 
Kaiser, W., \& Sarrafzadeh, W. (2010). Introduction to special issue on wireless health. ACM Trans. Embed. Comput. Syst., 10(1), 1-1.

Khawaja, M. A. (2010, April). Terrorism originates from the Western colonial powers. Global Research. Retrieved December 1, 2017 from https://www.globalresearch.ca/terrorism-originates-from-the-western-colonialpowers $/ 24104$

Kingsley, K. M., Johnson-Rokosu, S. F., \& Olanrewaju, R. A. (2015). Combating Boko Haram terrorism financing: Case of Nigeria and Lake-Chad Basin. International Journal of Current Research, 7(11), 22849-22861.

Landt, J. (2005). The history of RFID. IEEE Potentials, October - November. Retieved June 6, 2019 from https://ieeexplore.ieee.org/stamp/stamp.jsp?tp=\&arnumber=1549751\&tag=1

Laswell, H. (1948). The structure and function of communication in society. In L. Bryson (Ed.), The communication of ideas. New York: harper.

Lin, Y.-H., Jan, I.-C., Ko, P. C.-I., Chen, Y.-Y., Wong, J.-M., \& Jan, G.-J. (2004). A wireless PDAbased physiological monitoring system for patient transport. IEEE Trans. Inf. Technol. Biomed., 8(4), 439-447.

Michael, K., Michael, M. G., \& Ip, R. (2008). Microchip implants for humans as unique identifiers: A case study on VeriChip. In N. Manders-Huits (Ed.), Conference on ethics, technology and identity (ETI) (pp. 81-84). Delft: Delft University of Technology.

Moorthy, R., Benny, G., \& Gill, S. (2018). Disaster communication in managing vulnerabilities. Jurnal Komunikasi: Malaysian Journal of Communication, 43(2), 5166. doi: 10.17576/JKMJC-2018-3402-04

Mu'azu, A. (2015). Media use by insurgents and the application of media to counter Boko Haram. In O. O. Isola \& M. Popoola (Eds.), Journalism practice and terrorism in Nigeria: Issues, trends and techniques. Ibadan: John Archers Publishers Limited.

Muhammed, K. (2014). The message and methods of Boko Haram. In P. M. Marc-Antoine, P. M. (Eds.). Boko Haram: Islamism, politics, security and the state in Nigeria. Abuja: African Studies Center.

Nacos, B. L. (2002). Mass-mediated terrorism. New York: Rowman and Littlefield.

News18.com (2016, 1 July). Hajj pilgrims to get e-bracelete for safety: Media. Retrieved 15 November, 2018 from https://www.nes18.com/amp/news/world/hajj-pilgrims-toget-e-bracelets-for-safety-media-1264604.html

Ngige C. V., Badekale, A. F., \& HammanJoda I. (2016). The media and Boko Haram insurgency in Nigeria: A content analysis and review. International Journal of Peace and Conflict Studies, 3(1), 58-65.

Ogunnubi, O., Onapajo, H., \& Isike, C. (2016). A failing regional power? Nigeria's international status in the age of Boko Haram. Politikon, 44(3), 446-465.

Othman, Z., \& Mat, B. (2018). Jaringan komunikasi dan media: Satu analisis dari perspektif keselamatan insan. Jurnal Komunikasi: Malaysian Journal of Communication, 34(3), 21-39. doi: 10.17576/JKMJC-2018-3403-02

Oyeniyi, A. B. (2010). Terrorism in Nigeria: Groups, activities and politics. International Journal of Politics and Good Governance, 1(1), 1-16. 
Pate, A. U., \& Idris, H. (2017). How journalists survived to report: Professionalism and risk management in the reporting of terror groups and violent extremism in North East Nigeria (159-170). In U. Carlsson \& R. Poitra (Eds.), The assault on journalism: Building knowledge to protect freedom of expression (pp. 159-160). Gothenborg: Nordicom.

Premium Times. (2017, August 5). Boko Haram destroyed one million houses, 5,000 classrooms, N1.9 trillion properties in Borno - Official. Retrieved December 23, 2017 from https://www.premiumtimesng.com/regional/nnorth-east/239645-boko-haramdestroyed-one-million-houses-5000-classrooms-n1-9-trillion-properties-bornoofficial.html

Premium Times. (2015). We have defeated Boko Haram, December deadline met, Nigeria says. Premium Times Nigeria (Abuja), December 23. Retrieved October 302018 from http://www.premiumtimesng.com/news/headlines/195668-we-have-defeatedboko-haram-december-deadline-met-nigeria-says-2.html

Ramli, S. N., \& Ahmad, R. (2011). Surveying the wireless body area network in the realm of wireless communication. In 2011 7th International Conference on Information Assurance and Security (IAS), 2011, pp. 58-61.

Reuters. (2011, August 29). Islamist sect Boko Haram claims Nigerian UN bombing. (Reporter: Ibrahim Mshelizza). Retrieved January 11, 2015 from http://www.reuters.com/article/us-nigeria-bombing-claim-idUSTRE77S3ZO20110829

Rodriguez, D. A. (2019). Chipping in at work: Privacy concerns related to the use of body microchip ("RFID") implants in the employer-employee context. lowa Law Review, 104, 1581-1611.

Salaam, A. O. (2012). Boko Haram: Beyond religious fanaticism. Journal of Policing, Intelligence and Counter Terrorism, 7(2), 147-162.

Schmid, A., \& de Graaf, J. (1982). Violence as communication: Insurgent terrorism and the Western news media (pp. 178). London: Sage.

Siapera, E. (2018). Understanding new media (2nd ed.). London: Sage Publications.

Stephens, K. R. (2010). Colonial history, modernization and terrorism: The effect of colonialism and modernization on transnational ethnoseparatist terrorism, 19682002 (Published Master's thesis, the Graduate School of The Ohio State University, USA, pp. 56).

United Nations Security Council (UNSC). (2014). Security Council Al-Qaida Sanctions Committee adds Boko Haram to its sanctions list. Retrieved May 22, 2014 from http://www.un.org/press/en/2014/sc11410.doc.htm

US Department of State (USDS). (2016). Foreign terrorist organizations (Chapter 6). Retrieved October $\quad 21$, 2016 from https://www.state.gov/j/ct/rls/crt/2015/257523.htm

Warner, J., \& Matfess, H. (2017). Exploding stereotypes: The unexpected operational and demographic characteristics of Boko Haram's suicide bombers (pp. 1-44). Washington DC: Combating Terrorism Center at West Point.

Washington Post. (2016, April 14). Boko Haram kidnapped 276 girls two years ago. What happened to them? (Reporter: Kevin Sieff). Retrieved December 27, 2017 from https://www.washingtonpost.com/news/worldviews/wp/2016/04/14/boko-haramkidnapped-276-girls-two-years-ago-what-happened-to-them/ 
Wikipedia. (2017). Dabiq magazine. Retrieved December 23, 2017 from https://en.m.wikipedia.org/wiki/dabiq_(magazine)

Yao, J., Schmitz, R., \& Warren, S. (2005). A wearable point-of-care system for home use that incorporates plug-and-play and wireless standards. IEEE Trans. Inf. Technol. Biomed., 9(3), 363-371.

Zenn, J. (Ed.). (2018 May). Boko Haram beyond the headlines: Analyses of Africa's enduring insurgency. Washington, DC: Combatting Terrorism Center at West Point. 